\title{
INCREASED OIL PRODUCTION AND RESERVES UTILIZING SECONDARY/TERTIARY RECOVERY TECHNIQUES ON SMALL RESERVOIRS IN THE PARADOX BASIN, UTAH
}

Contract No. DE-FC22-95BC14988

Utah Geological Survey (UGS), Salt Lake City, Utah 84109

Submitted: October 16, 1995

Award Date: February 9, 1995

Anticipated Completion Date: February 8, 2000

Government Award for Current Fiscal Year: $\$ 786,880$

Principal Investigator: M. Lee Allison, UGS

Program Manager: Thomas C. Chidsey, Jr., UGS

Contracting Officer's Representative: Rhonda P. Lindsey, Bartlesville Project Office

Reporting Period: July 1 - September 30, 1995

\section{Objectives}

The primary objective of this project is to enhance domestic petroleum production by demonstration and technology transfer of an advanced oil recovery technology in the Paradox basin, southeastern Utah. If this project can demonstrate technical and economic feasibility, the technique can be applied to approximately 100 additional small fields in the Paradox basin alone, and result in increased recovery of 150 to 200 million barrels of oil. This project is designed to characterize five shallow-shelf carbonate reservoirs (Fig. 1) in the Pennsylvanian (Desmoinesian) Paradox Formation and choose the best candidate for a pilot demonstration project for either a waterflood or carbon dioxide-( $\left.\mathrm{CO}_{2}-\right)$ flood project. The field demonstration, monitoring of field performance, and associated validation activities will take place in the Paradox basin within the Navajo Nation. The results of this project will be transferred to industry and other researchers through a petroleum extension service, creation of digital databases for distribution, technical workshops and seminars, field trips, technical presentations at national and regional professional meetings, and publication in newsletters and various technical or trade journals. 


\section{DISCLAIMER}

This report was prepared as an account of work sponsored by an agency of the United States Government. Neither the United States Government nor any agency thereof, nor any of their employees, makes any warranty, express or implied, or assumes any legal liability or responsibility for the accuracy, completeness, or usefulness of any information, apparatus, product, or process disclosed, or represents that its use would not infringe privately owned rights. Reference herein to any specific commercial product, process, or service by trade name, trademark, manufacturer, or otherwise does not necessarily constitute or imply its endorsement, recommendation, or favoring by the United States Government or any agency thereof. The views and opinions of authors expressed herein do not necessarily state or reflect those of the United States Government or any agency thereof.

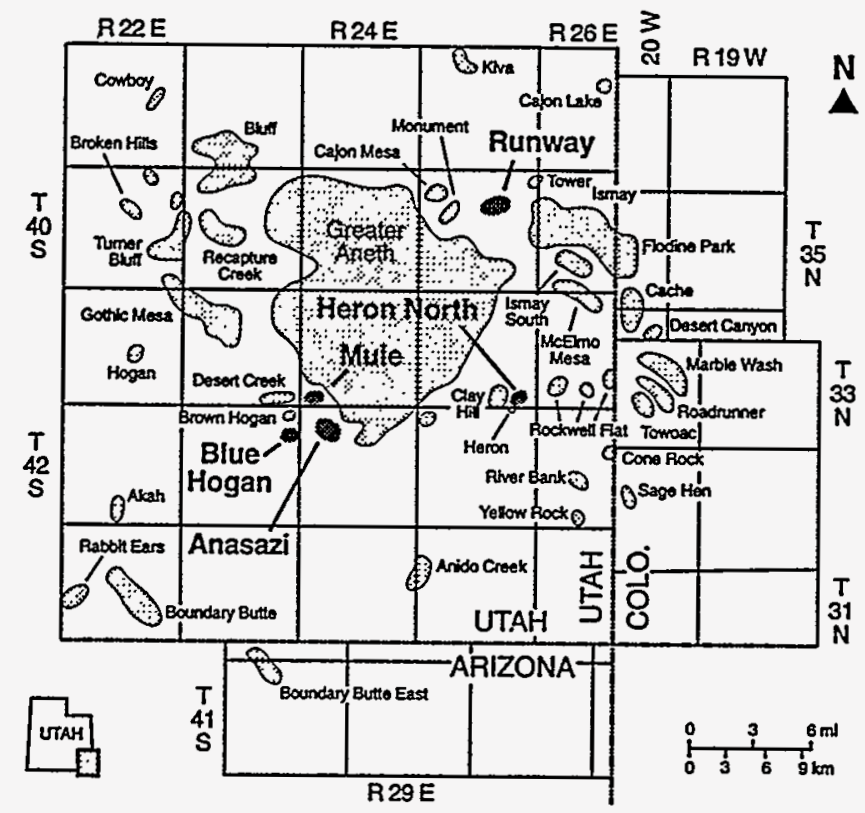

Figure 1. Five shallow-shelf carbonate fields (dark shading with names in bold type) on the Navajo Nation, San Juan County, Utah are targeted for geological and reservoir characterization. 


\section{Summary of Technical Progress}

Four activities continued this quarter as part of the geological and reservoir characterization of carbonate mound buildups in the Paradox basin: (1) field studies, (2) development well completion operations, (3) reservoir analysis and modeling, and (4) technology transfer.

\section{Field Studies}

During this quarter, base maps and new isochron maps covering project fields were prepared and cores were described from selected project wells with special emphasis on bounding surfaces of possible flow units. Reservoir data, conventional cores and cuttings, geophysical logs, and other information from the project fields and regional exploratory wells were collected by the Utah Geological Survey (UGS). Well locations, production reports, completion tests, core analysis, formation tops, and other data were compiled and entered in a database developed by the UGS for the 51 project wells.

The five project fields are Runway, Heron North, Anasazi, Mule, and Blue Hogan located in the Paradox basin of southeast Utah (Fig. 1); they are five of several satellite carbonate mounds around the Greater Aneth field (Eby et $a l^{l}$ ). Oil and gas are produced from the Pennsylvanian (Desmoinesian) Desert Creek and Ismay zones of the Paradox Formation. The fields were discovered in 1990 and 1991 as part of an ambitious exploration program conducted within the Navajo Nation by Chuska Energy Company (now Harken Southwest Corporation) and several Australian companies. Seismic surveys and subsurface geology were used to identify prospects. Each carbonate mound is expressed on seismic coverage (Fig. 2) by isochron thickening of the Desert Creek zone, isochron thinning of the overlying Ismay zone, amplitude dimming of the Desert Creek reflector, and a "doublet" development of the Desert Creek event (Johnson and Groen ${ }^{2}$ ).

Each field consists of one to three wells. Development wells are drilled on either 40-acre spacing or under the 80 -acre-spacing rules established at Greater Aneth field. Completion practices consist of selective perforation and treatment with varying amounts of acid. The reservoir drive is gas expansion. Primary production ranges from 700,000 to 2,000,000 bbls of oil per field at a 15 to $20 \%$ recovery rate. Geological and engineering data for each field are summarized on Table 1.

\section{Runway Field}

Runway field consists of three wells with the discovery well, the Runway 10-G-1, completed in 1990 at an initial potential flow (IPF) of $825 \mathrm{bbls}$ of oil per day (BOPD) and 895 thousand cubic feet of gas per day (MCFGPD) from commingled Desert Creek and upper Ismay zones. The Runway prospect was identified as a high-resolution, common-depth point seismic anomaly in the northern Aneth platform area. This anomaly, east of the Greater Aneth field (Fig. 3), is located on the upthrown edge of a basement-involved, Mississippian-age normal fault which was a high during Paradox Formation time.

The Runway field is a lenticular, west to east-northeast trending lobate mound, $0.9 \mathrm{mi}$ long and 0.5 mi wide. The reservoir consists of a bryozoan-dominated mound with phylloid algal 


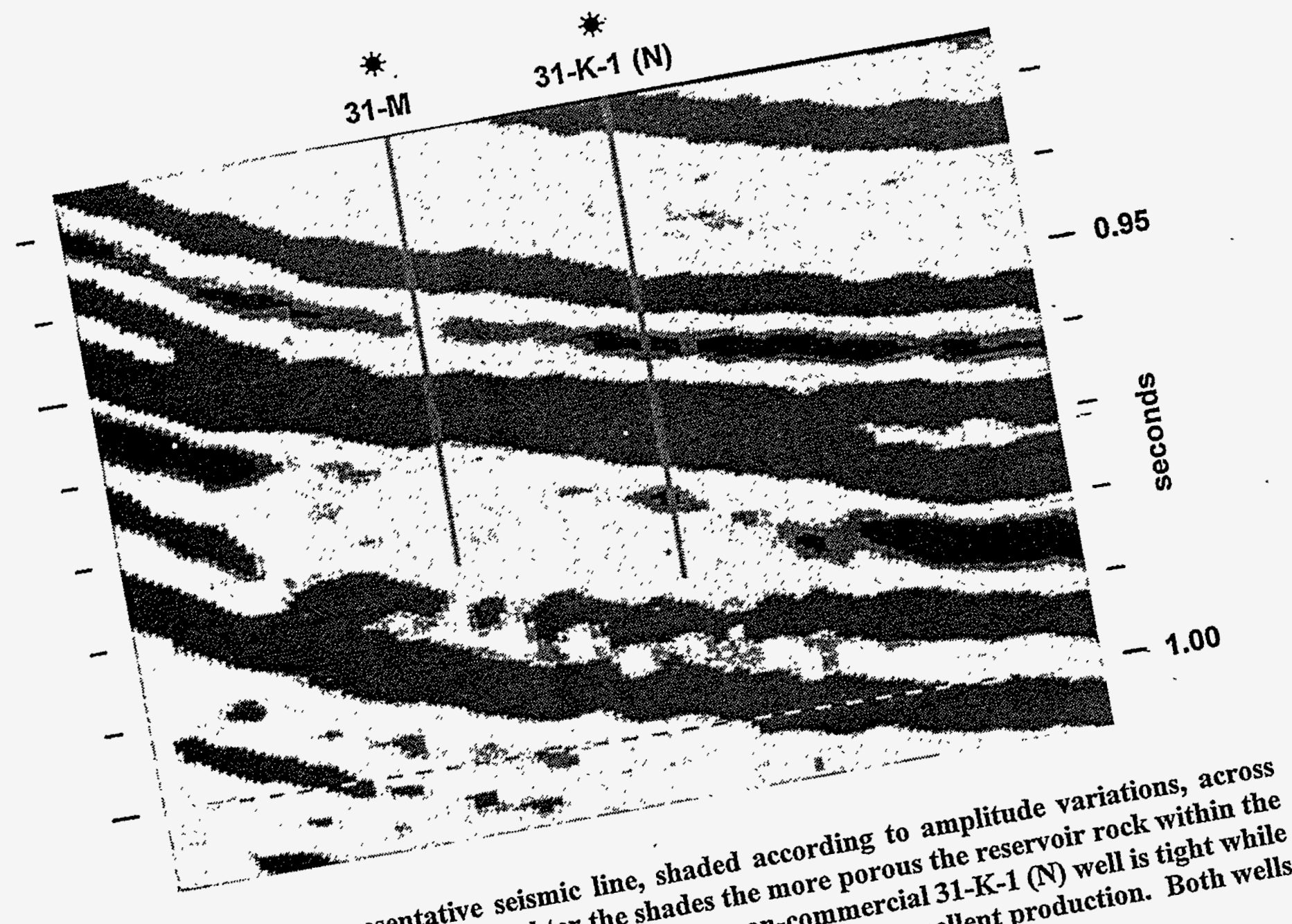

Figure 2. Representative seighter the shades non-commercial the lightent prod

Mule field. In gener. The reservoir rock porous, resulting in Cxunty, Utal. carbonate buildup. in the $31-M$ is more
the reservor rock 24 ., are located in 


\section{TABLE 1}

\section{Geological And Engineering Data For Project Fields}

In The Paradox Basin, San Juan County, Utah

\begin{tabular}{|c|c|c|c|c|c|c|c|c|}
\hline $\begin{array}{l}\text { Field } \\
\vdots \vdots \\
\vdots\end{array}$ & $\begin{array}{c}\therefore \text { Depth } \\
\therefore \text { (ft) } \\
\therefore\end{array}$ & $\begin{array}{l}\text { Area } \\
\text { (ac) }\end{array}$ & $\begin{array}{l}\text { pay: } \\
\therefore \text { (ft) } \\
\therefore \quad\end{array}$ & $\begin{array}{l}\text { Pörosity } \\
\text { (\%) }\end{array}$ & $\begin{array}{l}\text { Permeabilify } \\
\therefore \text { fmdl } \\
\therefore \text { a }\end{array}$ & $\begin{array}{l}\text { Water } \\
\text { Saturation } \\
\text { (f\%) }\end{array}$ & $\begin{array}{l}\text { Reservoir } \\
\text { Tepperature } \\
\text { prif }\end{array}$ & $\begin{array}{l}\text { Initial } \\
\text { Reservoir } \\
\text { Presture (psi) }\end{array}$ \\
\hline Runway & 5896 & 193 & 72 & 11.8 & 10.0 & 25.2 & 126 & 2162 \\
\hline Heron North & 5584 & 110 & 60 & 15.0 & 17.7 & 32.2 & 126 & 1934 \\
\hline Anasazi & 5574 & 165 & 57 & 14.1 & 135.3 & 28.1 & 138 & 1945 \\
\hline Mule & 5655 & 48 & 47 & 13.0 & 20.1 & 31.0 & 128 & 2050 \\
\hline Blue Hogan & 5400 & 89 & 82 & 9.1 & 33.6 & 29.0 & 128 & 1800 \\
\hline
\end{tabular}

*Average depth to the top of the reservoir. 


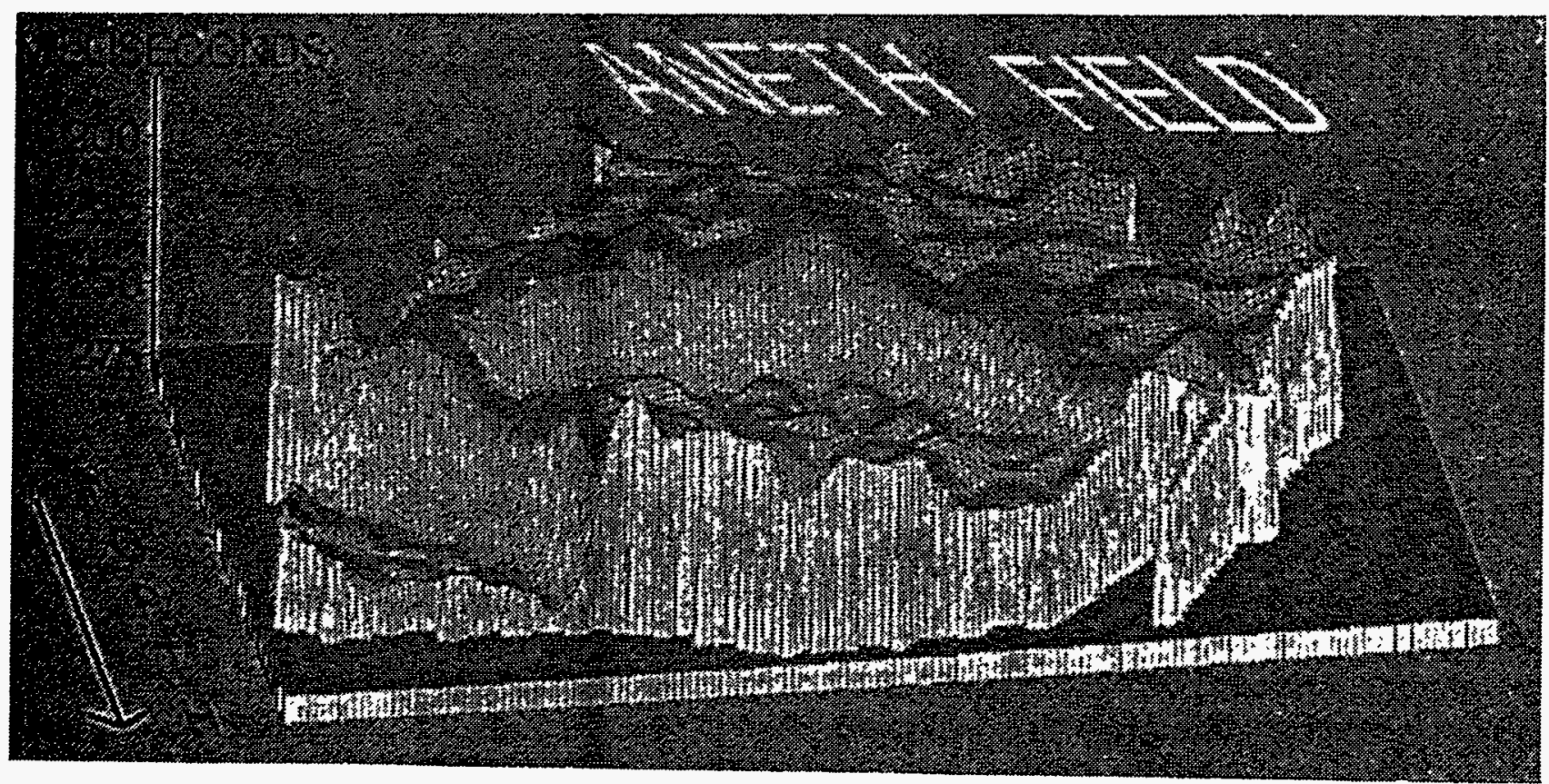

Figure 3. Three-dimensional "net" view to the southwest of the surface on top of the Mississippian Leadville Limestone and the north-bounding faults which control the localization of small algal and other carbonate buildups such as at the Runway field. This computerized presentation was produced from a closely spaced seismic grid. 
mound intervals. The presence of two mound types at Runway field suggests that the water depth changed as the carbonate deposits built up over the fault-controlled paleohigh. The principal Desert Creek reservoir rocks in the field are bindstone and framestone, rarely dolomitized, in the bryozoan-dominated interval and porous bafflestone (calcified plates of the green algae Ivanovia) with some grainstone and occasional dolomitization in the phylloid algal mound interval. The Ismay reservoir rock is sucrosic dolomite. Both carbonate buildups are interbedded with low permeability wackestone and mudstone.

Cumulative production from Runway field is $722,038 \mathrm{bbls}$ of oil (BO) and 2.064 billion cubic feet of gas (BCFG) as of January 1, 1995 (Utah Division of Oil, Gas and Mining $\left.[\mathrm{DOGM}]^{3}\right)$. Estimated primary recovery is $800,000 \mathrm{BO}$ and $2.99 \mathrm{BCFG}$.

\section{Heron North}

Heron North field, southeast of the Greater Aneth field, consists of one well, the North Heron 35-C, completed in 1991 at an IPF of 605 BOPD and 230 MCFGPD from the Desert Creek zone. The North Heron prospect was identified as a seismic anomaly.

The Heron North field is a lenticular, northwest to southeast trending linear mound/beach complex, $0.75 \mathrm{mi}$ long and $0.5 \mathrm{mi}$ wide. The reservoir consists of a bioclastic calcarenite mound above a anhydrite- and salt-plugged phylloid algal mound. This calcarenite mound type, which is also productive in the Heron $35-\mathrm{H}$ well $0.5 \mathrm{mi}$ southeast of Heron North, developed in a carbonate beach to foreshore environment with moderately high wave energy. Trough crossbedding is often present. The reservoir consists of alternating 2- to 4-ft-thick packages of uniform beach calcarenite and poorly sorted foreshore and storm lag rudstone or breccia deposits. An 8-ft-thick anhydrite lies immediately above the reservoir interval and creates an effective seal. The principal reservoir rocks in the field are porous, sucrosic, dolomitized grainstone and packstone (calcarenite) above tight bafflestone composed of algal stromatolitic mats. The calcarenite and bafflestone intervals are separated by low permeability, dolomitized wackestone and mudstone. Stylolitization, secondary cementation, and evaporite plugging are modest in the upper portion of the reservoir, but increase with depth. Pores are often lined with bitumen which in many instances plugs pore throats.

Cumulative production from Heron North field is 191,152 BO and 0.261 BCFG as of January $1,1995\left(\right.$ DOGM $\left.^{3}\right)$. Estimated primary recovery is $990,000 \mathrm{BO}$ and $2.65 \mathrm{BCFG}$.

\section{Anasazi Field}

Anasazi field consists of four wells. The discovery well, the Anasazi 1, was completed in 1990 at an IPF of 1705 BOPD and 833 MCFGPD from the Desert Creek zone. The Anasazi prospect, near the southwest edge of Greater Aneth field, was identified as a seismic anomaly along the east flank of the Desert Creek anticline. During the last contract quarter a modified seismic interpretation was completed for the field and converted into a gross Desert Creek isopach map.

Anasazi field is a lenticular, west to northeast trending lobate mound, $0.9 \mathrm{mi}$ long and 2000 to $3000 \mathrm{ft}$ wide. The reservoir consists of a phylloid algal mound. This mound type, which dominates the area southwest of Greater Aneth field, developed where shallow water depth and low wave energy allowed establishment of phylloid algal colonies on paleohighs. The principal reservoir rock in the field is porous algal bafflestone, some grainstone, and dolomitized zones 
interbedded with low permeable wackestone and mudstone. Extensive fresh water dissolution and early dolomitization has resulted in good to excellent porosity development and permeability modification.

Cumulative production from Anasazi field is 1,535,090 BO and 1.138 BCFG as of January $1,1995\left(\mathrm{DOGM}^{3}\right)$. Estimated primary recovery is 2,069,392 $\mathrm{BO}$ and 1.89 BCFG. Preliminary analysis of Anasazi field indicates the Desert Creek reservoir is a prime candidate for a $\mathrm{CO}_{2}$ miscible flood demonstration.

\section{Mule Field}

Mule field consists of two wells, the Mule 31-K-1 (N) discovery well and the Mule 31-M, completed in 1991 and 1992 respectively. The Mule 31-K-1 (N) well tested approximately 10 bbls of oil per hour (based on several swab tests) with water cut increasing on each test and produced only $283 \mathrm{BO}$ before being shut-in. The Mule 31-M offset well had an IPF of 735 BOPD and 97 MCFGPD from the Desert Creek zone. The Mule prospect, near the southwestern edge of the Greater Aneth field, was identified as a seismic anomaly. During the last contract quarter, a seismic program was laid out for the field and new seismic interpretations and mapping commenced.

The Mule field is a lenticular, northeast to east trending linear mound/mound flank deposit, $0.5 \mathrm{mi}$ long and $900 \mathrm{ft}$ wide. The reservoir consists of a phylloid algal mound combined with mound flank detrital deposits. Several beds in the Mule 31-K-1 (N) well core exhibit characteristics of mound flank deposits such as downslope gravity transport and sharp erosional basal contacts. The top of the phylloid algal interval is highly irregular with several cross-cutting zones of dissolution cavities possibly from karsting during subaerial exposure. The principal reservoir rock in the field is porous algal bafflestone (Fig. 4), crinoidal packstone, and dolomitized zones interbedded with low permeable wackestone, mudstone, and dolomite. Incomplete dolomitization and secondary anhydrite replacement have resulted in poor reservoir properties in some intervals.

Cumulative production from Mule field is $315,106 \mathrm{BO}$ and $0.178 \mathrm{BCFG}$ as of January 1 , $1995\left(\mathrm{DOGM}^{3}\right)$. Estimated primary recovery is $430,603 \mathrm{BO}$ and $0.288 \mathrm{BCFG}$.

\section{Blue Hogan}

Blue Hogan field consists of one well, the Blue Hogan 1-J-1, completed in 1991 at an IPF of 1167 BOPD and 722 MCFGPD from the Desert Creek zone. The Blue Hogan prospect, near the southwest edge of the Greater Aneth field, was identified as a seismic anomaly along the east flank of the Desert Creek anticline.

Blue Hogan field is a lenticular, northwest to southeast trending linear mound, $0.5 \mathrm{mi}$ long and $1000 \mathrm{ft}$ wide. The reservoir consists of a phylloid algal mound. The principal reservoir rock in the field is porous algal bafflestone and dolomitized zones interbedded with low permeability wackestone and mudstone.

Cumulative production from Blue Hogan field is $269,106 \mathrm{BO}$ and $0.239 \mathrm{BCFG}$ as of January 1, 1995 (DOGM ${ }^{3}$ ). Estimated primary recovery is 645,000 BO and 0.968 BCFG. 


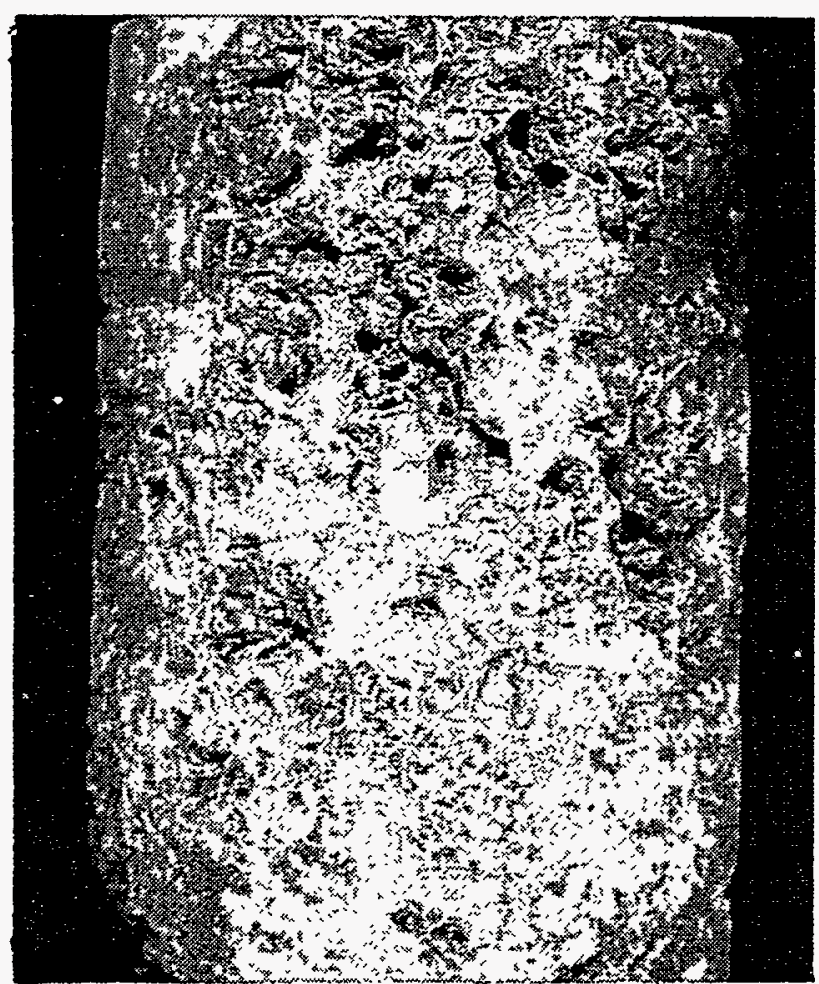

Figure 4. Core surface view of highly productive, dolomitized, phylloidal algal plate bafflestone from the Mule 31-M well, Mule field (see Fig. 2 for seismic line through well). Note good visual shelter porosity. Core diameter $=3.5 \mathrm{in}$. 


\section{Project Development Well Completion Operations}

The first project development well, the Anasazi $6 \mathrm{H}$ No. 1 in the Anasazi field (SE1/4NE1/4 section 6, T. 42 S., R. 24 E., Navajo Nation, San Juan County, Utah [Fig. 1]), was completed on September 15, 1995 for an IPF of 31.3 BOPD, 25 MCFGPD, and 7.5 bbls of water per day in the Desert Creek and Ismay zones. An algal bafflestone interval in the Desert Creek zone was perforated from 5723 to $5730 \mathrm{ft}$ and acidized. The resulting test indicated the pressure and permeability in the interval were too low to yield any meaningful data. A dolomite interval in the upper section of the Desert Creek was perforated from 5680 to 5694 . This interval was subsequently acidized and swab tested for 2 BOPD. After the swab test, a $200 \mathrm{hr}$ pressure buildup was run. A skin factor and permeability of +13 and 1.2 millidarcies (md) respectively was derived from the pressure buildup test. Given the high skin damage, the zone was reacidized. Several additional intervals were perforated including the upper Ismay zone from 5526 to $5531 \mathrm{ft}$. Production facilities have now been installed and the well flow rate has stabilized at 17 BOPD from the gross perforated intervals of 5664 to $5741 \mathrm{ft}$ and 5526 to 5531 ft.

\section{Reservoir Analysis and Modeling}

\section{Reservoir Analysis}

Conventional core was obtained from the Desert Creek zone of the Anasazi $6 \mathrm{H}-1$ well. Selected plugs from the reservoir are being used to determine oil/water and gas/oil relative permeability measurements. These data will be incorporated into the Anasazi reservoir flow simulation model. Whole core intervals were scanned using computerized axial tomography (CAT) techniques to ensure that permeability measurements are based on comparable pore systems. The three most homogeneous intervals were selected for additional analysis. Upon further examination and CAT scans, one interval appeared as the most homogeneous and contains the highest porosity. Four transverse plugs were taken from this interval for detailed CAT scans, and porosity and relative permeability measurements (Fig. 5). A variety of features were observed using these techniques including anhydrite-filled vugs, both micro-vuggy and intercrystalline porosity, patches of bitumen-filled pores, and areas of nonporous carbonate mudstone.

\section{Reservoir Modeling and Simulation}

The reservoir analysis for one of the project fields will be accomplished with a field-scale, compositional reservoir simulator. Both water flooding and $\mathrm{CO}_{2}$ flood are being evaluated. Permeability variations, reservoir pressures, production data, and other information are being incorporated into the simulation in order to accurately predict reservoir response. During the contract quarter, various one- and two-dimensional reservoirs models were created and tested.

Oil-water capillary pressure and relative permeability data were compiled into a data set suitable for reservoir simulator input. A one-dimensional, model initialization data set was also assembled for depletion analysis. Mechanistic one- and two-dimensional models and rate data deck were constructed. Pressure/volume/temperature (PVT) data from project fields were reviewed. This information will be entered into a computer program to develop a preliminary 


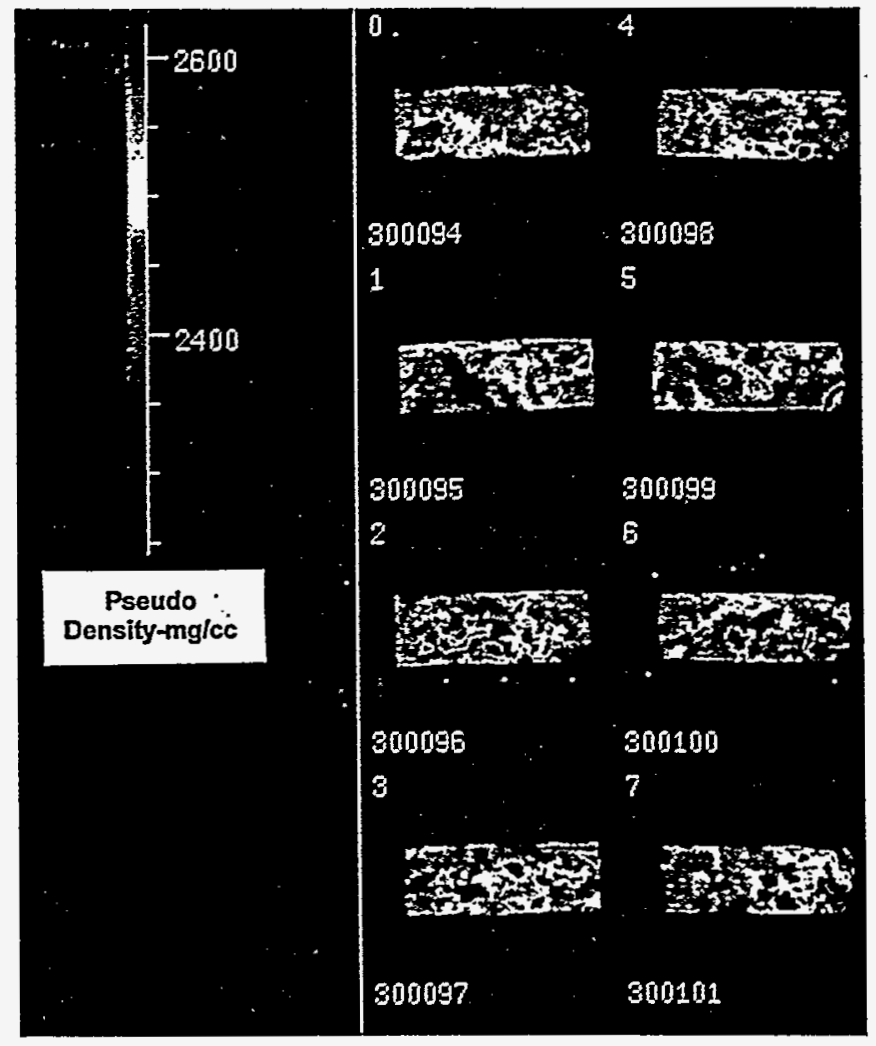

Figure 5. A set of CAT scans of two mutually perpendicular longitudinal-axial sections of each of the four core plugs taken to assess heterogeneity and select the most consistent intervals for measuring porosity and relative permeability in the Anasazi reservoir. 
equation of state from black-oil PVT data. The program will describe the dynamic equilibrium conditions of the fluids in the reservoir under various pressure, volumetric, and temperature conditions. As part of this task, gas-oil capillary pressure values were calculated from mercuryair capillary pressure measurements. Two preliminary equations of state $(9$ and 10 pseudo components [hydrocarbon components combined based on molecular weight]) were developed using Anasazi field and other PVT data from the area. Gas-oil and water-oil relative permeability tables were entered into the simulation model initialization data set. The Peng Robinson equation of state parameters were then added into the simulation model initialization data set. Initialization and recurrent data sets were built for a two-dimensional model. Preliminary equation of states were finalized including a new 13 component version from which parameters were generated for one- and two-dimensional composition simulation runs.

A series of one- and two-dimensional simulation runs were conducted. Model properties were adjusted to achieve an approximate match of field gas to oil ratios and pressures, and instructions were prepared for correcting the data set of field well rates that will be put into the simulator. Measured water-oil relative permeability curves were smoothed to give conventional shapes at low water saturations. The revised water-oil relative permeability tables and historic, monthly oil-production rates were added to the simulation input files. Solution techniques for the two-dimensional model were tested for speed and productivity. Indexes were calculated for the predictive phase of the one-dimensional model. The one-dimensional model was extended for a 25-year forecast period for Anasazi field.

The two-dimensional simulation was analyzed with a vertical to horizontal ratio of 0.02 md. Oil composition changes during the primary depletion were tabulated. The simulation model of the Anasazi history was extended to January 1996 and gas saturations, gas phase mole fractions, and oil-phase mole fractions were calculated for the dolomite and algal bafflestone intervals. The results were analyzed for a two-dimensional simulation case where a permeability barrier was placed between dolomite and algal bafflestone intervals which are present in Anasazi field wells. Then run files were created to extend the model without the permeability barrier to the year 2020 and forecast plots were prepared.

A two-dimensional simulation was run for a water-injection, repressurization case and after analyzing the results a series of repressurization runs were conducted to focus on the time and pressure when the gas saturation went to zero within a month and a day. The average oil composition was also plotted for the time the gas saturation went to zero. A one-dimensional suite of runs was designed to determine: (1) $\mathrm{CO}_{2}$ minimum miscibility pressure, (2) a $\mathrm{CO}_{2}$ flood with a back pressure of 2300 pounds per square inch absolute (psia), and (3) a $\mathrm{CO}_{2}$-flood case with a back pressure of 1700 psia. $\mathrm{CO}_{2}$ swelling and multi-contact studies were conducted with $\mathrm{CO}_{2}$ and original composition. A two-dimensional model case was created with a new producer on the west side of the Anasazi field and the incremental oil production was determined.

Several one-dimensional $\mathrm{CO}_{2}$-flood simulation cases were created, submitted, and analyzed to: (1) investigate grid sensitivity, (2) develop a recovery factor versus pressure relation, (3) evaluate conditions where oil has undergone primary depletion and repressurization, and (4) evaluate two layers with zero vertical permeability using the BLITZ equation solver comparing results against the GAUSS equation solver. The recovery factors were plotted versus pressure and a run was submitted to generate saturations and compositional arrays for a one-dimensional $\mathrm{CO}_{2}$ flood at 2600 psia. The data was tabulated to plot gas saturation, oil saturation, gas-phase mole fractions, and oil-phase mole fractions versus time for the middle cell.

Using data from the four wells in the Anasazi reservoir: (1) the average and standard 
deviation of porosity and water saturation were calculated for each of three lithologic intervals, and (2) density/lithology crossplots were constructed to develop a three-dimensional reservoir model. These data were compared to off-mound wells. A trend surface for the basal reservoir was developed and a grid translation/rotation formula determined. Two and three layer models were developed with cross flow to match pressure data. The seismic isolith map was digitized and an initial three-dimensional grid system was designed setting up a simulation initialization file for 15 and 20 layer cases.

\section{Technology Transfer}

Information on the Paradox basin project was shared with industry and the public at professional society meetings and through geological newsletters. Project materials were displayed at the UGS booth during the American Association of Petroleum Geologists Rocky Mountain Section meeting held in Reno, Nevada, July 16-19, 1995. The UGS released the August 1995 issue of Survey Notes and the July 1995 issue of Petroleum News both featuring articles about the Class II Paradox basin project. The purpose of Survey Notes is to provide nontechnical information on contemporary geologic topics, issues, events, and ongoing UGS projects to Utah's geologic community, educators, state and local officials and other decision makers, and the public. The purpose of Petroleum News is to keep petroleum companies, researchers, and other parties involved in exploring and developing Utah energy resources, informed of the progress on various energy-related UGS projects. Survey Notes is published three times yearly and Petroleum News is published semi-annually. Single copies are distributed free of charge and reproduction is encouraged with recognition of source.

Future technolgy transfer includes a Geology and Resources of the Paradox Basin symposium and field trip tentatively scheduled for September 1996 in Durango, Colorado. Sponsoring organizations are the Bureau of Indian Affairs, Utah Geological Survey, Colorado Geological Survey, U.S. Geological Survey, Utah Geological Association, Four Corners Geological Society, Fort Lewis College, and Ute Mountain Ute Indian Tribe. The two-day symposium will be preceded by a three-day field trip. The symposium will include poster and oral technical sessions, keynote addresses, and a UGS workshop presenting the results of the geological and reservoir characterization (phase 1 [budget period 1]) of the Class II Paradox basin project. The UGS will conduct visits to outcrop reservoir analogues and tours of production facilities of project fields during the field trip. A special guidebook will be published as part of the symposium and will include papers derived from the UGS project. 


\section{References}

1. D. E. Eby, W. G. Groen, and J. F. Johnson, Composition of Seismically Identified Satellite Mounds Surrounding Greater Aneth Field, Southeast Utah (abs), Am. Assoc. of Pet. Geol. Bull., 77(8): 1446-1447 (August 1993).

2. J. F. Johnson and W. G. Groen, Seismic Structure and Seismic Stratigraphy of the Giant Aneth Field and Its Satellite Fields of Southeast Utah (abs), Am. Assoc. of Pet. Geol. Bull., 77(8): 1452-1453 (August 1993).

3. Utah Division of Oil, Gas and Mining, Oil and Gas Production Report: (December 1994). 


\section{Next Quarter Activities}

Activities planned for the next quarter (October 1 through December 31, 1995) include:

1. Prepare a report on the major facies in the field reservoirs and produce a map of the general facies belts in the region.

2. Continue to describe cores, cuttings, and geophysical logs from project field wells. Define layers or units with bounding surfaces for the Desert Creek reservoir in Anasazi field.

3. Continue thin section petrography of Anasazi wells in order to: (a) establish a catalog of grain types and depositional facies, (b) develop a display and catalog of major porosity types as seen in thin sections, (c) develop a display of typical porosity types and lithology as a function of log response, and (d) construct a diagenetic history for the reservoir zones.

4. Continue data collection. Well information such as oil, gas, and water analyses; core descriptions; reservoir tops; and other data will be entered into the UGS database for manipulation.

5. Continue work on various reservoir maps for project fields. Complete seismic interpretations at Mule field.

6. Prepare for and conduct outcrop work on phylloid algal mounds exposed along the San Juan River as reservoir analogues both in sequence stratigraphic framework and depositional patterns.

7. Conduct relative permeability and phase behavior work. Develop preliminary EOS (based on original PVT studies) for the laboratory phase behavior program and preliminary onedimensional composition simulation. Set up the one-dimensional reservoir analogue compositional simulator to study preliminary depletion performance from compositional stand point and produce preliminary $\mathrm{CO}_{2}$ design once the updated EOS is developed. Compare current tuned EOS and original compositions to revised EOS and new compositions.

8. Evaluate petrophysical models of the five project fields utilizing geophysical logs and conventional core data on new petrophysical software. Integrate pressure transient work with petrophysical work.

9. Develop geostatistical layering and grid design for Anasazi reservoirs. Assemble constraining and well condition datasets for incorporation into the reservoir model. Finalize three-dimensional exterior simulation grid. 
10. Conduct the following technology transfer activities: (a) submit an abstract on the project fields for presentation at the 1996 American Association of Petroleum Geologists (AAPG) national convention in San Diego, California, (b) write and submit an abstract(s) on the project for presentation at the 1996 AAPG Rocky Mountain Section convention in Billings, Montana (c) complete and submit papers on the five project fields for the Utah Geological Association (UGA) Publication 22 entitled Oil and Gas Fields of Utah, second edition, (d) prepare the January issue of the UGS Petroleum News, (e) present an oral paper entitled "Composition of Seismically Identified Pennsylvanian Satellite Mounds Surrounding the Greater Aneth Field: Implications for Increased Oil Production Utilizing Secondary/Tertiary Recovery Techniques" to the Fort Worth Geological Society (November 13, 1995), and (f) continue planning for the Geology and Resources of the Paradox Basin symposium sponsored by the Bureau of Indian Affairs, UGS, UGA, U.S. Geological Survey, Colorado Geological Survey, Four Corners Geological Society, Fort Lewis College, and Ute Mountain Indian Tribe. A UGS workshop presenting the results of phase 1 (budget period 1) will be part of this symposium. 